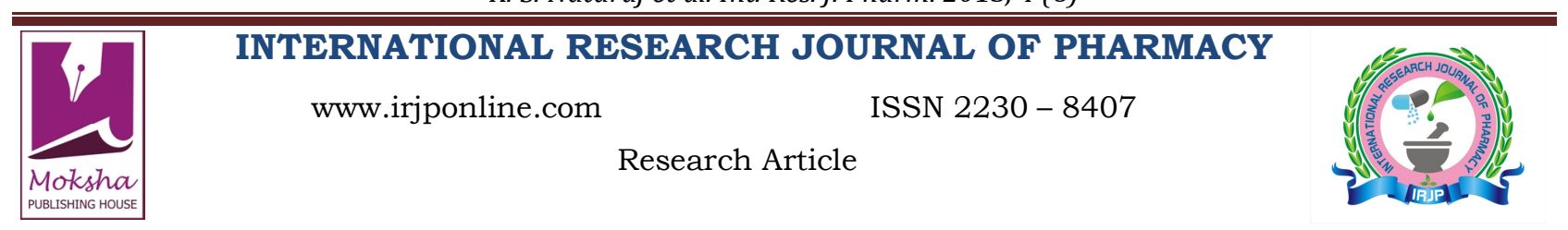

\title{
METHOD DEVELOPMENT AND VALIDATION FOR SIMULTANEOUS ESTIMATION OF OFLOXACCIN AND SATRANIDAZOLE BY USING RP-HPLC
}

K. S. Nataraj*, A. Srinivasa Rao, Nagesh Kumar Mutyala, P. Sivalingachari and K. Alekhya

Shri Vishnu College of Pharmacy, Bhimavaram, West Godavari (Dt), Andhra Pradesh, India

*Corresponding Author Email: kalakondan@yahoo.com

Article Received on: 10/07/13 Revised on: 21/07/13 Approved for publication: 01/08/13

DOI: $10.7897 / 2230-8407.04848$

IRJP is an official publication of Moksha Publishing House. Website: www.mokshaph.com

(C) All rights reserved.

\section{ABSTRACT}

A new simple, accurate, rapid and precise gradient High Performance Liquid Chromatographic (HPLC) method was developed and validated for simultaneous estimation of Ofloxaccin and satranidazole in combined dosage form. The method employs waters HPLC system on Hypersil BDS C 18 Column (250 mm X 4.6 $\mathrm{mm}, 5 \mu$ ), with a flow rate of $1.0 \mathrm{ml} / \mathrm{min}$ with a load of $10 \mu \mathrm{l}$. Water + OPA (Ortho Phosphoric Acid) having $\mathrm{pH} 5.0$ and acetonitrile was used as a mobile phase in the composition of 60:40\% v/v. The detection was carried out by PDA detector at $295 \mathrm{~nm}$. Linearity ranges for Ofloxaccin and satranidazole were $100-300 \mu \mathrm{g} / \mathrm{ml}$ for Ofloxaccin, $150-450 \mu \mathrm{g} / \mathrm{ml}$ for satranidazole respectively. Retention time of Ofloxaccin and Satranidazole were found to be 2.881 minutes, 4.042 minutes respectively. Percent recovery study values of Ofloxaccin and Satranidazole were found to be $99.003-100.5 \%$ and $98.6-100.4 \%$ respectively. This newly developed method was successfully utilized for the quantitative estimation of Ofloxaccin and Satranidazole in combined pharmaceutical dosage forms. This method was validated as per ICH guidelines.

Keywords: Ofloxaccin, Satranidazole RP - HPLC, validation, simultaneous estimation.

\section{INTRODUCTION}

Ofloxaccin is chemically 9-fluoro-2, 3-dihydro-3-methyl-10(4-methyl-1-piperazinyl)-7-oxo-7H-Pyrido [1, 2, 3-de]-1, 4benzoxacine-6-carboxylic acid] (Figure 1). Ofloxaccin acts on DNA gyrase and topoisomerase IV, enzymes which, like human topoisomerase, prevents the excessive super coiling of DNA during replication or transcription. By inhibiting their function, the drug thereby inhibits normal cell division. Satranidazole is chemically 1-(1-Methyl-5-nitro- $1 \mathrm{H}-$ imidazol-2-yl)-3-(methylsulfonyl)-2-imidazolidinone (Figure 2), is a nitro imidazole's which have broad spectrum bactericidal activity against Protozoa and some anaerobic bacteria. Its selective toxicity to anaerobic microbes involves

- Drug enters the cell by diffusion,

- Nitro group of drug is reduced by redox proteins present only in anaerobic organisms to reactive nitro radical which exerts cytotoxic action by damaging DNA and other critical biomolecules.

- DNA helix destabilization and strand breakage has been observed.

Literature survey reveals the availability of several UV spectroscopy $^{1,2}$ and RP - HPLC $^{3-7}$ methods for estimation of Ofloxaccin and Satranidazole. The current available methods are developed for very short runtime and the resolution was also less. The objective of the present work was to develop and validate new analytical method which provides improved analytical identification or detection limits, greater resolution, accuracy and precision.

\section{MATERIALS AND METHODS Instrumentation}

High performance liquid chromatography (waters) with quarternary pump, PDA detector and with Hypersil BDS $\mathrm{C}_{18}$ Column $(250 \mathrm{~mm} \mathrm{X} 4.6 \mathrm{~mm}, 5 \mu)$ was used. The detection of drug was carried by UV detector data processing by Empower - 2 software, weighing balance (Mettler Toledo), sonicator (Elma S $300 \mathrm{H})$, pH meter (Inolab WTW series).

\section{Reagents and Chemicals}

Methanol (HPLC grade), water (HPLC), Potassium dihydrogen O-phosphate (GR Merck Chemicals), OPhosphoric Acid (AR Rankem), Acetonitrile (GR Merck Chemicals) and pure drug samples of Ofloxaccin and Satranidazole are gift samples from Rainbow pharma training lab, Hyderabad, India.

\section{Chromatographic Condition}

The analysis was carried out by HPLC using Water + OPA (Ortho Phosphoric Acid) having pH 5.0 as buffer and acetonitrile was used as a diluent in the composition of 60:40 $\% \mathrm{v} / \mathrm{v}$ and this was used as a mobile phase and Hypersil BDS $\mathrm{C}_{18}$ Column (250 mm X $\left.4.6 \mathrm{~mm}, 5 \mu\right)$ as a stationary phase at a flow rate of $1.0 \mathrm{ml} / \mathrm{min}$, in isocratic mode. With the above mobile phase good resolution between Ofloxaccin and Satranidazole was achieved with a run time of 20 minutes. The injection volume was $10 \mu \mathrm{l}$ and the detection was performed at $295 \mathrm{~nm}$. (Figure 5)

\section{Solution Preparation}

\section{Preparation of Buffer solution (pH 5.0)}

Accurately measured quantity of $1000 \mathrm{ml}$ of HPLC Grade water was taken and its $\mathrm{P}^{\mathrm{H}}$ was adjusted to 5.0 with $5 \%(\mathrm{v} / \mathrm{v})$ Ortho-phosphoric acid solution and degassed.

\section{Preparation of Mobile Phase}

Buffer and Acetonitrile were mixed in the ratio of $60: 40 \mathrm{v} / \mathrm{v}$ respectively and degassed.

\section{Preparation of Diluent}

Mobile phase was used as the diluent.

\section{Preparation of Standard Solution}

Required quantity was weighed accurately and about $30 \mathrm{mg}$ of Satranidazole working standard, $20.2 \mathrm{mg}$ of Ofloxaccin working standard was transferred into a $100 \mathrm{ml}$ volumetric flask and dissolved in $20 \mathrm{ml}$ diluent by sonicating for 10 minutes and was made up to the volume with diluent. The 
above solution was filtered through $0.45 \mu \mathrm{m}$ PVDF membrane filter.

\section{Calibration Curves}

Linearity experiments were performed by giving five replicates for both the components and the response was found to be linear in the range of 100 to $300 \mathrm{ppm}$ for Ofloxaccin and 150 to $450 \mathrm{ppm}$ for Satranidazole. The linearity of Ofloxaccin and satranidazole was plotted by a graph between response factor and concentration. (Figure $3,4)$.

\section{Analysis of Tablet Formulation}

A quantity of the mixed contents was weighed accurately that is 20 tablets equivalent to about $200 \mathrm{mg}$ of Ofloxaccin and transferred into a $100 \mathrm{ml}$ volumetric flask. $20 \mathrm{ml}$ of diluent was added and sonicated for about 10 minutes and diluted to the volume with diluent. $5 \mathrm{ml}$ of the above solution was further diluted to $50 \mathrm{ml}$ with diluent and mixed. The above solution was filtered through $0.45 \mu \mathrm{m}$ PVDF membrane filter.

\section{Procedure}

The column was equilibrated for not less than 30 minutes with initial gradient at a flow rate of $1.0 \mathrm{ml} / \mathrm{min} .10 \mu \mathrm{l}$ of blank solution (Diluent), standard solution (5 injections) and sample solution were injected separately into the chromatographic system. The chromatograms were recorded and the peak responses were measured.

\section{Validation of HPLC Method Specificity}

The specificity of the RP - HPLC method was determined by comparison of the chromatogram of mixed standard and sample solution which were injected separately and the parameters like retention time, resolution and tailing factor were calculated. Good correlation was found between the results of mixed standards and sample solutions.

\section{Precision}

Precision of proposed HPLC method was found to be 0.309 $\left(\begin{array}{ll}\% & \text { RSD })\end{array}\right.$ for Ofloxaccin and 0.168 (\% $\left.\mathrm{RSD}\right)$ for

Table 1: Linearity of Detection Response for Ofloxaccin

\begin{tabular}{|c|c|}
\hline \multicolumn{2}{|c|}{ Ofloxaccin } \\
\hline Conc. (mcg) & Area \\
\hline 100 & 197812 \\
\hline 150 & 286544 \\
\hline 200 & 385706 \\
\hline 250 & 475264 \\
\hline 300 & 581348 \\
\hline
\end{tabular}

Table 3: Method Precision for Ofloxaccin

\begin{tabular}{|c|c|c|}
\hline Parameters & Rt (min) & Area \\
\hline \multirow{3}{*}{ Ofloxaccin } & 2.891 & 388313 \\
\cline { 2 - 3 } & 2.892 & 390522 \\
\cline { 2 - 3 } & 2.892 & 389639 \\
\cline { 2 - 3 } & 2.891 & 391354 \\
\cline { 2 - 3 } & 2.892 & 388315 \\
\hline & 2.891 & 389832 \\
\hline Mean & 2.892 & 389662 \\
\hline SD & 0.00054 & 1206 \\
\hline \% RSD & 0.309 & 0.3 \\
\hline
\end{tabular}

Satranidazole that indicates good precision of the sample analyzed. Table 3,4 shows the data.

\section{Accuracy (Recovery Studies)}

Accuracy of method was calculated by recovery studies $(\mathrm{n}=$ 6) at six levels. Standard drug solution containing drugs in the range for Ofloxaccin and Satranidazole of concentration was added to previous analyzed test solution. Amount of drug recovered at each level $(\mathrm{n}=6)$ was determined. Percent recovery at each level was calculated. Table 5,6 shows data from the recovery study for Ofloxaccin, satranidazole were $99.003-100.5 \%$ for Ofloxaccin, $98.6-100.4 \%$ for satranidazole, respectively. High percentage recovery showed that the method was free from interference of excipients used in formulation.

\section{Robustness}

Robustness of the method was checked by changing flow rate, temperature, and standard was able to give system suitability parameters with in limit, which indicates that the method is robust results are shown in Table 7.

\section{System Suitability Parameters}

The system suitability parameters were evaluated. The \% RSD for five replicate injections of Ofloxaccin and Satranidazole was 0.309 and 0.168 and found to be within the limits. The tailing factors for Ofloxaccin and satranidazole peaks were 1.6 and 1.16 respectively. The theoretical plates for Ofloxaccin and satranidazole are 41549 and 6809 were found to be within the limits. The system suitability parameters were evaluated and found to be within the limits. Results are shown in Table 8.

\section{RESULTS AND DISCUSSION}

The proposed method was a RP - HPLC procedure which employed a Hypersil BDS $\mathrm{C}_{18}(250 \mathrm{~mm}$ X $4.6 \mathrm{~mm}, 5 \mu)$ column. Water + OPA ( $\mathrm{pH} 5.0)$ and acetonitrile in the composition of $60: 40 \% \mathrm{v} / \mathrm{v}$ was used as the mobile phase. The drug solutions were scanned in the range of 200 to 400 $\mathrm{nm}$ on a UV - Visible spectrophotometer for selection of sampling wavelength. After recording the spectra of the two drugs, $295 \mathrm{~nm}$ was selected as a suitable wavelength for estimation.

Table 2: Linearity of Detection Response for Satranidazole

\begin{tabular}{|c|c|}
\hline \multicolumn{2}{|c|}{ Satranidazole } \\
\hline Conc. (mcg) & Area \\
\hline 150 & 261480 \\
\hline 225 & 379584 \\
\hline 300 & 514161 \\
\hline 375 & 636879 \\
\hline 450 & 775303 \\
\hline
\end{tabular}

Table 4: Method Precision for Satranidazole

\begin{tabular}{|c|c|c|}
\hline Parameters & Rt (min) & Area \\
\hline \multirow{3}{*}{ Satranidazole } & 3.839 & 520209 \\
\cline { 2 - 3 } & 3.841 & 520637 \\
\cline { 2 - 3 } & 3.841 & 522053 \\
\cline { 2 - 3 } & 3.841 & 519693 \\
\cline { 2 - 3 } & 3.841 & 522381 \\
\cline { 2 - 3 } & 3.840 & 519934 \\
\hline Mean & 3.834 & 520818 \\
\hline SD & 0.0161 & 1133.04 \\
\hline \%RSD & 0.168 & 0.2 \\
\hline
\end{tabular}


K. S. Nataraj et al. Int. Res. J. Pharm. 2013, 4 (8)

Table 5: Accuracy Results of Ofloxaccin

\begin{tabular}{|c|c|c|c|c|c|c|}
\hline Drug & Sample & Sample weight (mcg) & Amount Added (mcg / ml) & Amount Estimated (mcg / ml) & \% Recovery & \% mean \\
\hline \multirow[t]{15}{*}{ Ofloxaccin } & $50 \%-01$ & 320.0 & 100.6 & 102.9 & 102 & \multirow[t]{6}{*}{102} \\
\hline & $50 \%-02$ & 320.0 & 100.6 & 103.8 & 102 & \\
\hline & $50 \%-03$ & 320.0 & 100.6 & 102.2 & 102 & \\
\hline & $50 \%-04$ & 320.0 & 100.6 & 102.8 & 102 & \\
\hline & $50 \%-05$ & 320.0 & 100.6 & 103.3 & 103 & \\
\hline & $50 \%-06$ & 320.0 & 100.6 & 100.63 & 100 & \\
\hline & $100 \%-01$ & 636.0 & 200.0 & 195.41 & 98 & \multirow[t]{3}{*}{98} \\
\hline & $100 \%-02$ & 636.0 & 200.0 & 198.32 & 99 & \\
\hline & $100 \%-03$ & 636.0 & 200.0 & 195.17 & 98 & \\
\hline & $150 \%-01$ & 953.0 & 299.6 & 297.19 & 99 & \multirow[t]{6}{*}{100} \\
\hline & $150 \%-02$ & 953.0 & 299.6 & 298.9 & 100 & \\
\hline & $150 \%-03$ & 953.0 & 299.6 & 299.6 & 100 & \\
\hline & $150 \%-04$ & 953.0 & 299.6 & 298.5 & 100 & \\
\hline & $150 \%-05$ & 953.0 & 299.6 & 302.12 & 101 & \\
\hline & $150 \%-06$ & 953.0 & 299.6 & 301.59 & 101 & \\
\hline
\end{tabular}

Table 6: Accuracy Results of Satranidazole

\begin{tabular}{|c|c|c|c|c|c|c|}
\hline Drug & Sample & Sample weight (mcg) & Amount Added (mcg / ml) & Amount Estimated (mcg / ml) & \% Recovery & $\%$ mean \\
\hline \multirow[t]{15}{*}{ Satranidazole } & $50 \%-01$ & 320.0 & 150.9 & 152.9 & 101 & \multirow[t]{6}{*}{101} \\
\hline & $50 \%-02$ & 320.0 & 150.9 & 154.3 & 102 & \\
\hline & $50 \%-03$ & 320.0 & 150.9 & 154.5 & 102 & \\
\hline & $50 \%-04$ & 320.0 & 150.9 & 153.5 & 102 & \\
\hline & $50 \%-05$ & 320.0 & 150.9 & 153.7 & 103 & \\
\hline & $50 \%-06$ & 320.0 & 150.9 & 147.0 & 97 & \\
\hline & $100 \%-01$ & 636.0 & 300.0 & 293.2 & 98 & \multirow[t]{3}{*}{98} \\
\hline & $100 \%-02$ & 636.0 & 300.0 & 293.0 & 98 & \\
\hline & $100 \%-03$ & 636.0 & 300.0 & 291.7 & 97 & \\
\hline & $150 \%-01$ & 953.0 & 449.5 & 445.1 & 99 & \multirow[t]{6}{*}{100} \\
\hline & $150 \%-02$ & 953.0 & 449.5 & 444.2 & 99 & \\
\hline & $150 \%-03$ & 953.0 & 449.5 & 447.6 & 100 & \\
\hline & $150 \%-04$ & 953.0 & 449.5 & 445.6 & 99 & \\
\hline & $150 \%-05$ & 953.0 & 449.5 & 460.7 & 102 & \\
\hline & $150 \%-06$ & 953.0 & 449.5 & 451.4 & 100 & \\
\hline
\end{tabular}

Table 7: Robustness for Ofloxaccin and Satranidazole

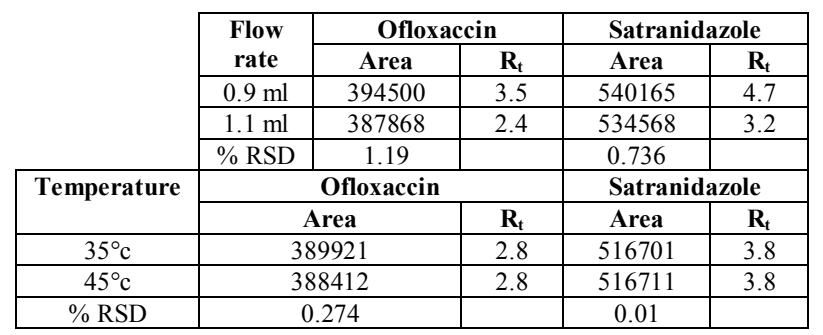

Table 8: System Suitability

\begin{tabular}{|c|c|c|c|c|}
\hline Parameters & Rt & Resolution & Theoretical plates & Tailing factor \\
\hline \multirow{4}{*}{ Ofloxaccin } & 2.890 & -- & 5705 & 0.98 \\
\cline { 2 - 5 } & 2.890 & -- & 5684 & 1.02 \\
\cline { 2 - 5 } & 2.891 & -- & 5624 & 1.06 \\
\cline { 2 - 5 } & 2.892 & -- & 5584 & 1.12 \\
\cline { 2 - 5 } & 2.891 & -- & 5494 & 1.15 \\
\hline Satranidazole & 3.838 & 5.24 & 6982 & 0.93 \\
\cline { 2 - 5 } & 3.838 & 5.31 & 6914 & 0.96 \\
\cline { 2 - 5 } & 3.838 & 5.45 & 6863 & 0.99 \\
\cline { 2 - 5 } & 3.839 & 5.52 & 6798 & 1.05 \\
\cline { 2 - 5 } & 3.839 & 5.60 & 6732 & 1.18 \\
\hline
\end{tabular}

Table 9: Results of LOD LOQ

\begin{tabular}{|c|c|c|}
\hline Sample & LOD Value $(\boldsymbol{\mu g} / \mathbf{m l})$ & LOQ Value $(\boldsymbol{\mu g} / \mathbf{~ m l})$ \\
\hline Ofloxaccin & 1.37 & 7.0 \\
\hline Satranidazole & 2.0 & 10.6 \\
\hline
\end{tabular}


<smiles>CC1COc2c(N3CCN(C)CC3)c(F)cc3c(=O)c(C(=O)O)cn1c23</smiles>

Figure 1: Ofloxaccin structural Formula<smiles>Cn1c([N+](=O)[O-])cnc1N1CCN(S(C)(=O)=O)C1=O</smiles>

Figure 2: Satranidazole structural Formula

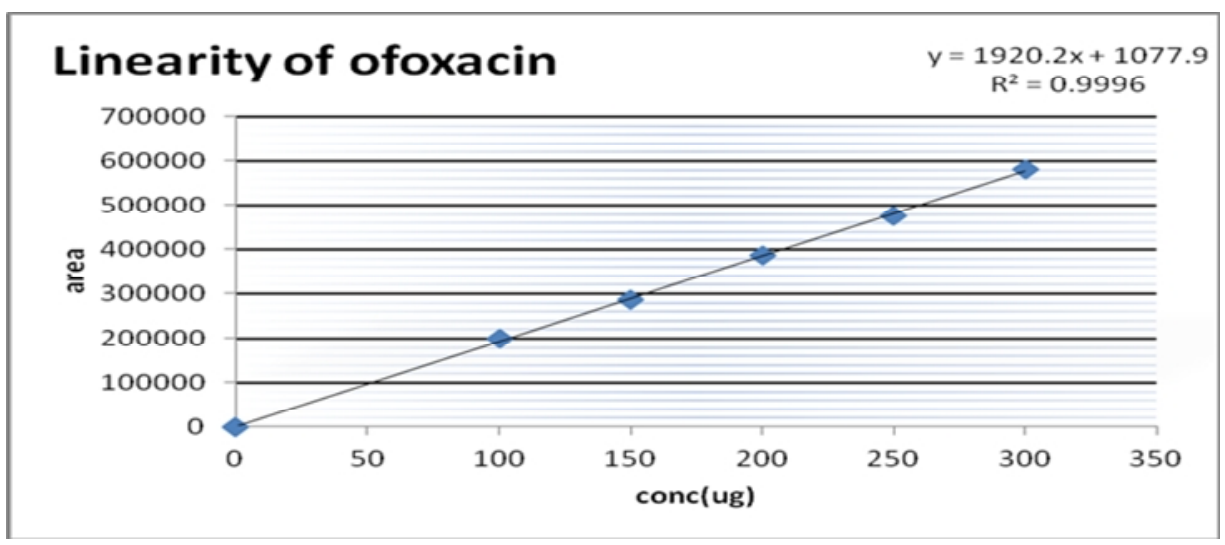

Figure 3: Linearity Curve for Ofloxaccin

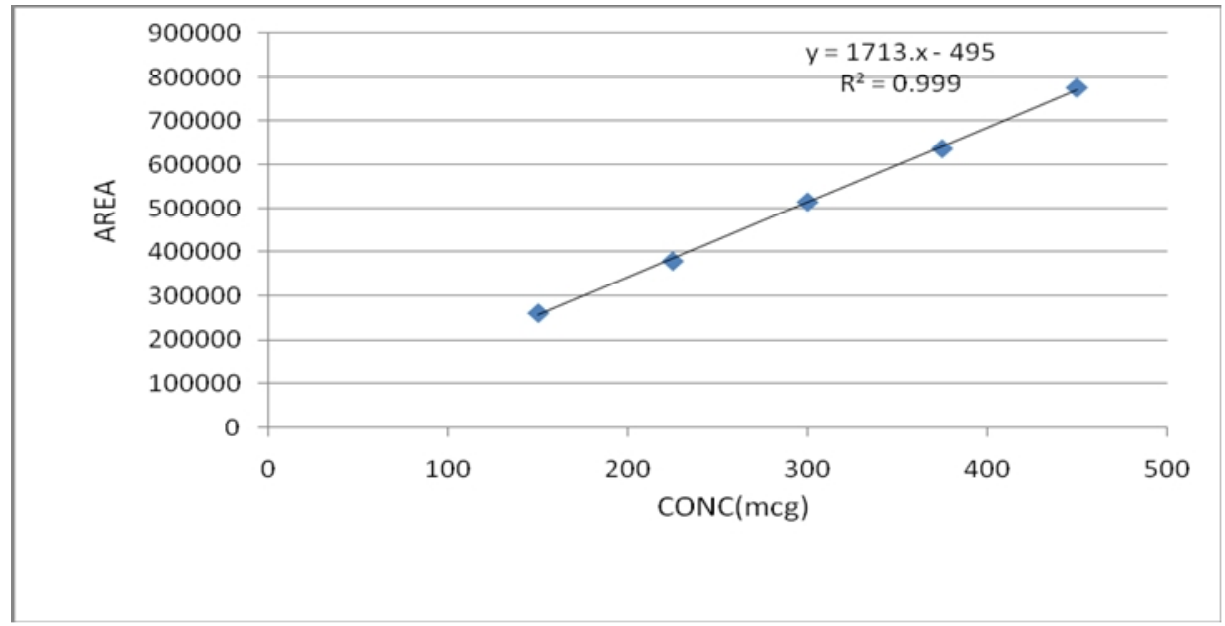

Figure 4: Linearity Curve for Satranidazole

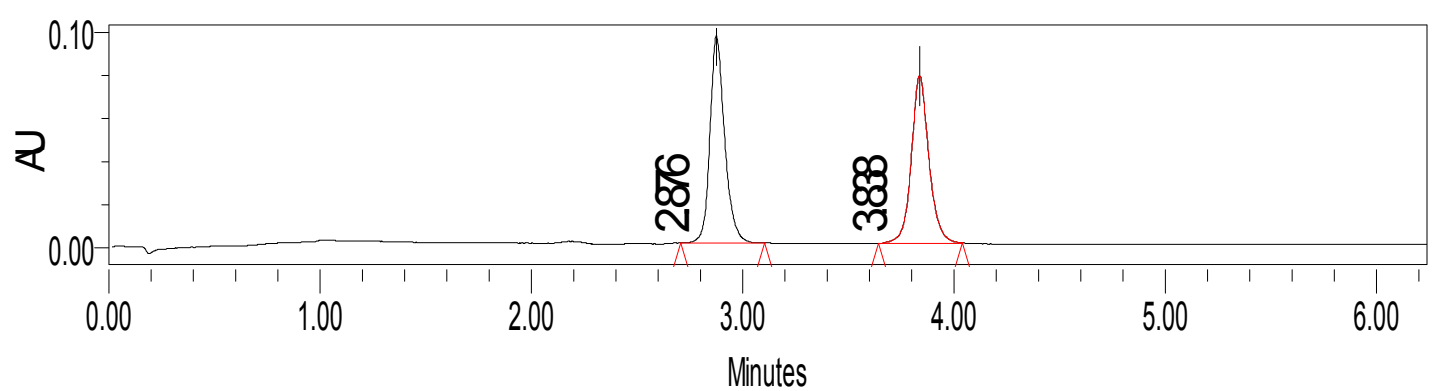

Figure 5: Typical Chromatogram of Ofloxaccin and Satranidazole

\begin{tabular}{|c|c|c|c|c|c|c|c|c|}
\hline Name & RT & Area & \% Area & Height & Resolution & s/n & USP Tailing & USP Plate Count \\
\hline Ofloxaccin & 2.876 & 463601 & 50.78 & 96190 & & 122.81 & 1.233 & 8862 \\
\hline Satranidazole & 3.838 & 449289 & 49.22 & 77557 & 7 & 99.02 & 1.095 & 10917 \\
\hline
\end{tabular}


The best resolution between Ofloxaccin and Satranidazole was achieved with in 6 minutes of run time, with flow rate of $1.0 \mathrm{ml} / \mathrm{min}$. The linearity response of the HPLC system for Ofloxaccin was found to be in the range of 100 to $300 \mathrm{ppm}$ and for Satranidazole in the range of 150 to $450 \mathrm{ppm}$. Accuracy of the method was checked by adding standard drug solution containing drugs within the range. The recovery study for Ofloxaccin was between $99.003-100.5 \%$ and 98.6 - $100.4 \%$ for Satranidazole. Precision of the method was found to be 0.309 (\% RSD) for Ofloxaccin and 0.168 (\% RSD) for Satranidazole that indicates good precision of the sample analyzed. When changing the flow rate and temperature of the method, the system suitability parameters remained within limits, so that the method was proved to be robust. The LOD, LOQ values of Ofloxaccin were 1.37, 7.0 and Satranidazole 2.0, 10.6 respectively (Table 9). The other validation parameters, sensitivity and selectivity of the proposed method were found be within limits as the number of theoretical plates, tailing factor, resolution, separation factor, results of analysis and statistical parameters.

\section{CONCLUSION}

The present work describes simple, economical and noninterfering simultaneous method of estimation of Ofloxaccin and Satranidazole by using RP - HPLC. The method was found to be economic, simple, precise, accurate and reproducible during analysis of drug formulations containing the two drugs.

\section{REFERENCES}

1. Dash Arun Kumar, T. Siva Kishore, Loya Harika, Uma Devi Kothapalli. A Validated UV-Spectrophotometric method for the estimation of Ofloxaccin in bulk and Pharmaceutical dosage forms, International Journal of Pharmaceutical and biological archives 2011; 2(4): 11571161.

2. Rao Kareti Srinivasa, Benarjee Arijit, Keshar Nargesh Kumar. Spectrophotometric methods for the simultaneous estimation of Ofloxaccin and tinidazole in bulk and dosage forms, Chronicles of young scientists articles 2011;2(2): 98-102.

3. Sherje AP, Tawade AP. Simultaneous spectrophotometric estimation of Ofloxaccin and Satranidazole from pharmaceutical dosage form, International Journal of Pharmatech Research 2010; 2(1): 5111-5114.

4. R Shinde Sachin, I Bhoir Suvarna, S Pawar Namdev, B Yadav Suman and M Bhagwat Ashok. Simultaneous Estimation of Satranidazole and Ofloxaccin in Tablet Dosage Form by High Performance Liquid Chromatography, Journal of chemistry 2010; 7(1): 198-202.

5. Bhatt KK, Patel NS, Patel JB, Jadeja J, Chaudhary B. Simultaneous Estimation of Ofloxaccin and Satranidazole in tablet by RP-HPLC method, International Journal of Pharmaceutical and Applied Sciences 2011; 2(1): 11-14.

6. Archana Raveendran, T Venkatachalam, N Senthil Kumar. RP-HPLC Method for Simultaneous determination of Ofloxaccin and satranidazole in tablet dosage form, Journal of Global Trends in Pharmaceutical sciences 2011;2(3): 415-420.

7. Suvarna I Bhoir, Poonam V Gaikwad, Lavu S Parab. RP-HPLC Method Development and Validation for the Simultaneous Estimation of Satranidazole and Ofloxaccin in Pharmaceutical Dosage Form, Journal of chromatographic science 2009; 49(1): 84-87.

Cite this article as:

K. S. Nataraj, A. Srinivasa Rao, Nagesh Kumar Mutyala, P. Sivalingachari and K. Alekhya. Method development and validation for simultaneous estimation of ofloxaccin and satranidazole by using RP-HPLC. Int. Res. J. Pharm. 2013; 4(8):240-244 http://dx.doi.org/10.7897/2230-8407.04848 